\title{
A cidade divorciada de si, em Divórcio, de Ricardo Lísias
}

\author{
Vera Lopes da Silva*
}

\begin{abstract}
Resumo
Este artigo apresenta um estudo da relação entre cidade e voz discursiva presente em Divórcio, de Ricardo Lísias, obra literária brasileira contemporânea que manifesta certa desconfiança quanto ao próprio trabalho de escritor de literatura, desconfiança evidenciada por meio de um recurso estético relativo ao elemento composicional da narrativa: o espaço urbano. Inquieta, a voz discursiva, que se encarna no narrador, não se fixa, está sempre em deslocamentos físicos ou mentais, como se fosse impulsionada para o entendimento de si. Sendo assim, pela impermanência em que se coloca, é revelado um embaraço, um dilema, um mal-estar quanto à sua existência, problema que se apresenta sob certa aura de fascínio, cuja resolução se dá na e pela construção da escrita, revelando o tempo em que se inscrevem, a contemporaneidade, tudo elucidado pela errância no espaço.
\end{abstract}

Palavras-chave: Vozes discursivas. Narrador. Escritor.Espacialidade.Cidade.

\section{The City Divorced from Itself, in Divórcio, by Ricardo}

\begin{abstract}
This work presents a study between city and discursive voice as presented in Divórcio, by Ricardo Lísias, a brazillian contemporary literary work which manifests distrust about the very work of the literary writer, a suspicion which is evidenced through a aesthetic resource relative to the compositional element of the narrative: the urban environment. Restless, the discursive voice, which incarnates itself in the narrator, does not settle down, rather it is always in physical or mental motion, as if boosted towards self comprehension. Thus, through the impermanence which it puts itself in, an embarrassment, a dilemma, a feeling of uneasiness about its existence is revealed, a problem which shows itself under a certain aura of awe and is cured in and by the construction of the writing, revealing the times when contemporaneity is registered, all of it being clarified through its wanderingness.
\end{abstract}

Keywords: Discursive voices. Narrator.Literaturewriter.Spaciality.City

Recebido: $30 / 03 / 2018$

Aceito: $26 / 09 / 2018$

* Pontifícia Universidade Católica de Minas Gerais (PUC Minas). Professora do Departamento de Letras. 


\section{Introdução}

Este artigo trata da construção de vozes na sua relação com o espaço da e na narrativa na obra ficcional brasileira contemporânea Divórcio, de Ricardo Lísias(2013). Peculiarmente não ocorre, na obra em estudo, a construção de uma voz discursivanum espaço onde se ancore, mas entremeada à construção de um espaço faltoso. Sendo um escritor, função que se desenvolve mais consistentemente no meio urbano, essa voz não permanece nos espaços em que estaria, poderia estar, gostaria de estar salvaguardada; até não olha para esses espaços, não os reconhece nem se reconhece neles; por vezes, passar por eles é sofrido, repassar por eles, uma catarse. Assim, suas ações são deslocamentos físicos e/ ou mentais, como aventura (in)voluntária para o deciframento de si. Trata-se de uma voz desajustada, que não olha para o entorno porque não se vê nele ou não quer se ver nele. Tem dificuldade no reconhecimento de si mesmo, sentindo um mal-estar de si na sua existência, problema cuja lida perpassa a vivência no espaço urbano.

Para o desenvolvimento das reflexões, o tratamento desse quadro de relações entre narrador/ personagem e espaço se dará mediante o embasamento em alguns teóricos, entre eles mais significativamente George Wink(2015), em seu artigo "Topografias literárias e mapas mentais: a sugestão de espaços geográficos e sociais na literatura", no qual discorre sobre como o espaço narrado é organizado, qual é a sua relação com o espaço "real” e sobre qual é a função dessa organização em relação às estratégias narrativas. E também Luís Alberto Brandão, em Teorias do espaço literário (2013), estudo no qual trata de privilegiar a geografia nas obras literárias, recompondo a espacialização como um estratégia de transgressão que transita em espaços cujo perfil não é exatamente geográfico. (BRANDÃO, 2013, p.20). Outros, como Carlos Reis e Ana Cristina M Reis, Franco Moretti, Gaston Bachelar, Julia Kristeva e Silvana Pessôa, também contribuirão para as reflexões.

Usufruindo, então, desses estudiosos, a composição deste trabalho se dá por uma divisão assim manifesta: um primeiro segmento, do qual consta um aparato teórico; um segundo, que traz a leitura da obra (subjacente à qual estão as teorias antes apresentadas) em suas estratégias estéticas relativas à relação voz discursiva-espaço, fomentada pela agregação de outros elementos que compõem a espacialidade; e um terceiro, no qual se apresenta uma reflexão final, quando se tenta alinhavar as ideias desenvolvidas.

\section{$2 \mathrm{~A}$ teoria que se inteira na obra}

A atuação da categoria espaço na obra Divórcio, de Ricardo Lísias(2013), vai ao encontro de uma manifestação peculiar da literatura contemporânea: a de uma instabilidade espacial externa que ilustra esteticamente a instabilidade interna. A dificuldade de vozes manifestas em obras atuais, quer seja o narrador quer seja um personagem, de centrar-se no espaço, de ter nele um apoio, traduz-se por meio de mecanismos que retratam a desconfiança que tem(têm) de si, ou seja, formalmente, atua(m) de modo a demonstrar sentir(em)-se desalojados, sem lugar no lugar em que habitam. No caso da voz narrativa da obra de Lísias, dá-se uma procura identitária, dentro da cidade, transitando por si e por ela.

$\mathrm{Na}$ conjunção de teorias que atendem nossas reflexões, Franco Moretti, em sua obra Atlas do romance europeu (2003), estuda obras europeias que lhe permitiram perceber duas funções exercidas 
pelo espaço. A primeira delas realça - "literalmente traduzido por preso, ligado ou vinculado ao lugar" - (MORETTI, 2003, p.15, nota de rodapé), o que seria "a natureza espacial das formas literárias: cada uma delas com sua geometria peculiar, suas fronteiras, seus tabus espaciais e rotas favoritas" (MORETTI, 2003, p.15). A segunda traz "à luz a lógica interna da narrativa: o domínio semiótico em torno do qual um enredo se aglutina e se organiza" (MORETTI, 2003, p.15). Isso significa que uma força externa e outra interna dão a forma literária ao texto, o que põe em evidência a interação entre sociedade e literatura. Assim Moretti nos ensina que a percepção da geografia pela qual transitam as vozes estéticas muda nossa maneira de apreender o objeto literário.

Usufruindo ainda das reflexões do ensaísta, com base na fala dos cartógrafos, de que um mapa vale mais que mil palavras (MORETTI, 2003, p. 14), é por meio do mapeamento que vamos acompanhar o estado de pensamento da voz discursiva que se manifesta em Divórcio, de Ricardo Lísias(2013). Não se trata de um protagonista cujo percurso é apenas decorativo. Pelo contrário, seus movimentos externos ilustram seu interior, havendo motivações para a construção do "onde", do "por onde", do "aonde". A busca dessas motivações nos leva a perceber como os espaços configuram-se como estratégia reveladora dessa obrada literatura contemporânea brasileira, cuja forma se alicerça no deslocamento, na impossibilidade da fixidez, no desconforto.

É assim que ocorre, esteticamente, o que parece ser uma incongruência: a geografia que constitui o alicerce da forma narrativa da obra se apresenta errante, perdida, desestabilizada, sem alicerçamento.

A voz sob nosso foco não tem asilo, não tem onde "con-viver" com suas dores, é um ser "descentrado”. Sua geografia é errante. Como veremos no próximo segmento, não tem terra, casa, veredas nem palavra nua onde se encostar, perdido em sua condição interna. Essa posição des-centrada em que se forja a obra ilustra que "o espaço constitui uma das mais importantes categorias da narrativa, não só pelas articulações funcionais que estabelece com as restantes categorias, mas também pelas incidências semânticas que o caracterizam", conforme a conceituação do verbete "espaço", no Dicionário de narratologia (REIS; LOPES, 1987, p.129), e anuncia a relevância da categoria para os efeitos de sentido gerados na sua incongruência com o espaço urbano.

Georg Wink (2015), em seu artigo “Topografias literárias e mapas mentais: a sugestão de espaços geográficos e sociais na literatura”, entende que o espaço acolhe a ação e o movimento dos personagens, sendo amplo ou limitado; protagonista ou mero acessório; inventado ou alusivo a uma geografia real. Em qualquer dessas situações, no entanto, o espaço narrado, "geralmente, não é criado de forma ingênua ou coincidental, mas, sim, pertence às estratégias narrativas e, portanto, cumpre uma função de relevância para a análise literária” (WINK, 2015, p.21). Sendo assim, para empreender a compreensão de como o espaço se desenha na obra literária em estudo, algumas perguntas devem ser feitas a ela: Onde se desenvolve e por quê? Ou, mais precisamente: Como o espaço narrado é organizado e qual é a sua relação com o espaço "real"? Qual é a função dessa organização em relação às estratégias narrativas? Os espaços narrados trazem à tona lacunas e distorções, nos sentidos topográfico (proximidades, distâncias, divisões) e político-social (segregação, assimetrias, representatividade), que podem permitir reconsiderações sobre a função social da obra literária? E, mais adiante, a criação de mapas, mentais ou reais, além de ser um efeito da produção e recepção do texto, também poderia ser usufruída como uma ferramenta analítica na interpretação do texto? (WINK, 2015, p.21-22).

Traçando um quadro mais abrangente da categoria espaço, Luís Alberto Brandão, em sua obra Teorias do espaço literário (2013), dialoga com a proposição de Edward W. Soja, que põe em questão "a primazia derivada do preceito de que o espaço é mero cenário para o desenrolar do tempo". Conforme o autor, a pós-modernidade se caracteriza pelo projeto de "abrir e recompor o território da imaginação histórica através da espacialização crítica", projeto que corresponde à reversão da tendência, dominante nas análises sociais em vigor no século XIX, “de privilegiar o tempo e a história 
em detrimento do espaço e da geografia” (BRANDÃO, 2013, p.20).

Percorrendo esse viés, Brandão faz alguns estudos nos quais insere o conceito de "espacialidade" distinto de "espaço", ou seja, que não diz respeito.

[...] ao modo como o texto literário representa espaços extratextuais. Na verdade, o termo atua na direção contrária, ou seja, tornando viável que, no âmbito da literatura, se estimule e se vivencie a problematização do que é entendido como espaço. Isso ocorre mediante a crítica ao próprio pressuposto de que a categoria espaço é autoevidente, de que determina a si mesma, ou de que não passa de um dado oferecido passivamente à percepção e à conceptualização (BRANDÃO, 2013, p. 175).

O estudioso apresenta três modelos de espacialidade, pautando-se em obras de Rafael Courtoisie Música para Sordos (1971), Umbría (1999), Estado sólido (1996)), sobre as quais discorremos brevemente, para que delas possamos usufruir nas reflexões que faremos quando, no segmento seguinte, nos debruçarmos mais detalhadamente sobre Divórcio, de Ricardo Lísias(2013).

O primeiro modelo é o espaço tátil, em que se trata o espaço como categoria material. Essa percepção, embora já seja conhecida na teoria estruturalista, nos estudos de Roland Barthes, em Octavio Paz e em Gaston Bachelard, é agora apresentada com singularidade, pois a materialidade não é considerada segundo qualidades ou estados físicos, mas comportando matérias não afins ou cuja afinidade não é óbvia, com imprevisibilidades na relação matéria-objeto, como se não houvesse mais a crença na estabilidade das coisas.

O segundo modelo é o espaço visivo, em que "o espaço configurado/apreendido pela visão é aquele que, em princípio, exige a distância entre o observador e o observado. É essa distância que define a própria nitidez da visibilidade resultante" (BRANDÃO, 2013, p.179). Os objetos, no caso, perdem lugar para as formas, criando ambivalências "entre o tocado e o formalizado, a proximidade e a distância, a percepção e a representação” (BRANDÃO, 2013, p.179).

O terceiro modelo é o espaço dinâmico. No caso, o espaço

[...] pode ser abordado não como uma categoria de base, determinante de outras categorias, mas como resultante, como um efeito; a momentânea cristalização de processos em estados (que podem se revelar em graus de incerteza maiores ou menores) (BRANDÃO, 2013, p. 180).

Por serem conceituados como efeitos de deslocamentos, em seu cerne estão as noções de movimento e de tempo.

Os três modelos se cruzam, sobrepõem-se, acoplam-se, de tal forma que "o espaço tátil pode tender a se desmaterializar, tornando-se impalpável, preferencialmente só movimento" (BRANDÃO, 2013, p.181), o que não significa algo em harmonia, pois o terceiro modelo coloca em questão a própria noção de matéria:

Se a mão, ao tocar, é capaz de fugir à propensão de tratar objetos e espaços de modo escópico, visual, formal; as matérias tornam-se inatingíveis, pois que em constante transformação — ou, mais propriamente, porque se tornam o próprio vetor que determina a transformação (BRANDÃO, 2013, p. 181).

As considerações teóricas vistas neste segmento perpassarão a partir de agora nossos estudos sobre a voz discursiva e seu modo de atuação relacionado à espacialidade, na tentativa de demonstrar como o espaço se aloja em Divórcio, de Ricardo Lísias (2013). 


\section{A obra que se inteira da teoria}

Santos e Oliveira(2001), em suas reflexões na obra Sujeito, tempo e espaço ficcionais, começam o capítulo "Espaço e Literatura", com a seguinte pergunta: "É possível ser sem estar?" E continuam:

De maneira geral, quando concebemos um determinado ente — seja humano ou não, animado ou inanimado - criamos uma série de referências com as quais ele se relaciona de algum modo. Ou seja: imaginamos uma forma de situá-lo, atribuímos ao ser um certo estar. Ao realizarmos tal operação, estamos produzindo um espaço para o ser. (SANTOS; OLIVEIRA, 2001, p. 67).

A obra Divórcio, de Ricardo Lísias(2013), coloca sob suspeição essa relação entre ser e estar, começando por um primeiro capítulo cujo foco narrativo, em primeira pessoa, encena ver-se fora de si mesmo: representa não ser e, portanto, não estar, colocando-se como alguém que não é um vivo e também não é um morto:

Depois de quatro dias sem dormir, achei que tivesse morrido. Meu corpo estava deitado na cama que comprei quando saí de casa. Olhei-me de uma distância de dois metros e, além dos olhos vidrados, tive coragem apenas para conferir a respiração. Meu tórax não se movia, Esperei alguns segundos e conferi de novo.

A gente vive a morte acordado.

Nos momentos seguintes, não sei o que aconteceu. Tenho pontos obscuros na minha vida entre agosto e dezembro de 2011. Neles, devo estar morto. (LÍSIAS, 2013, p.7).

Esse narrador olha para seu corpo como se fosse um outro, alguém do lado de fora dele, "a uma distância de dois metros", vendo seus olhos de morto, percebendo-se sem respiração, como um espírito desencarnado de seu corpo e observador de si mesmo, simulando estar de fora. Situação nonsense, configura-se nela um personagem olhando para um outro personagem que é ele próprio: ele mesmo é um outro, de tal forma dissociados e indissociáveis. Tomado de forte sensorialidade, descreve-se como se as sensações fossem ao mesmo tempo alheias e suas - sente seu corpo cair, estende o braço, choca-se com a cama e sente ardência, porque seu "corpo estava sem pele" (LÍSIAS, 2013, p. 7). Assim desnudado, sem pele, o narrador vê a complexidade de si mesmo, seu estado interior, sem roupagens, desprotegido, morto. A imagem um tanto kafkaniana consolida um espaço de linguagem, composto de uma descrição em frases curtas, instantâneas ("Não consegui. Meu estômago encolheu. Senti falta de ar" (LÍSIAS, 2013, p. 8)), que comandam os movimentos do narrador ante o personagem que é ele mesmo, como se ele estivesse dirigindo uma cena ("Agora, distanciei-me um pouco" (LÍSIAS, 2013, p. 8)), aproximando ou distanciando sua câmera, buscando o melhor ângulo de si, um convite para uma leitura a ser feita pela empatia de sensações do leitor, que acompanha o trânsito de movimentos: enquanto o narrador-personagem, com o braço direito, vira para conferir "se o caixão continuava no mesmo lugar" (LÍSIAS, 2013, p. 8); enquanto se distancia um pouco e respira fundo; enquanto se apoia na parede; a cada movimento do narrador-personagem, o leitor move os olhos, sente o ar respirado, contata a parede fria. Então, o corpo, com suas reações atalhadas por outras ("Tive dificuldade para abrir os olhos. Minhas mãos latejavam. Um clarão distante me deixou com tontura. Um corpo em carne viva é quente" (LÍSIAS, 2013, p. 8)), entrecortadas pelo discurso composto de frases curtas, estanques, é a base da percepção espacial em que se dá aquela imagem de morte a se desfazer, reavivada pelos mesmos sentidos que, levados ao extremo na sensação da loucura, lançam o narrador para a busca de um estado de vida, de estar e, então, de ser:

Não me lembro das horas seguintes. Por volta da meia-noite, nervoso por ter enlouquecido, saí para andar. Quando cheguei a uma avenida bastante movimentada, fiz a primeira das muitas promessas que colocaria na cabeça nos meses seguintes: Morro só mais uma vez. (LÍSIAS, 2013, p.8). 
A cena inicial ilustra aquilo que Brandão (2013) afirma ser uma problemática espacial de alta complexidade, na qual se tensionam os significados de espaço disseminados e as experiências espaciais usuais em âmbito literário, de forma que a categoria espaço é posta em um deslimite. Trata-se de desfamiliarizar elementos extratextuais que passam a ter significações heterotópicas, com "ênfase naquilo que diferencia (ou melhor, discrimina) certos lugares, naquilo que torna não trivial a sua condição" (BRANDÃO, 2013,p.248).

A perspectiva de Brandão orienta a leitura de três localizações anunciadas no início de enredo da obra Lísias - e desenvolvidas ao longo do romance -, no que tange a espaços extratextuais: uma casa da qual em algum momento o narrador-personagem saíra ("Meu corpo estava na cama que comprei quando saí de casa" (LÍSIAS, 2013, p. 7)); o espaço onde ele está e de onde ele sai para andar - o que dali a pouco será denominado "cafofo" ("Por volta da meia-noite, nervoso por ter enlouquecido, saí para andar" (LÍSIAS, 2013, p. 8)); a rua ("Quando cheguei a uma avenida bastante movimentada [...]" (LÍSIAS, 2013, p. 8)). Dois deles são espaços de dentro - casa e cafofo; outro, espaço de fora - rua. Os três, entrelaçados e configurados no meio urbano, todos destituídos de sua função localizante e passam à função de representar o estado de desestabilização do narrador. São, assim, áreas parte do espaço urbano que quebram a estabilidade em que, tradicionalmente, se situam, porque carregam elementos que ali se configuram também de forma inusual - como espaços de atuação do narrador-personagem: na casa, a desproteção imputada ao narrador pela leitura do diário; no cafofo, a exposição de um corpo desnudado; na rua, ainda a centralidade do corpo, mas sendo reconstruído para ser o abrigo de si mesmo, pela reconstrução de sua pele. Toda essa espacialidade se dá pela encenação de um narrador que se personifica na função de um escritor. Sendo assim, trata-se de um escritor sem coordenadas, perdido em sua vida pessoal e profissional, que, esteticamente, configura sua descoordenação desdobrando espaços em outros espaços, assim revelando o modo como os percebe, melhor dizendo, como se percebe neles. A cidade não se mostra, então, como um espaço totalizante, mas apresenta-se entrecortada em seus espaços, e sua função será a de espelhamento também de alguém não totalizado, mas visto em suas fragmentações.

A casa, um microespaço do espaço urbano, vista por Bachelard como "o nosso canto do mundo [...] nosso primitivo universo, [...] um verdadeiro cosmos. Um cosmos em toda acepção do termo" (BACHELARD, 1988, p.24), é, na obra em estudo, o espaço promotor do caos. O enredo nos conta de um narrador-personagem, cujo nome é Ricardo Lísias, também um escritor. Ele é casado com uma jornalista há quatro meses, vivendo com ela sob o mesmo teto, onde, circunstancialmente, encontra seu diário, no qual estão registrados comentários negativos sobre ele. Essa leitura traumatizante altera o rumo de sua vida: tira-o da casa, colocando-o em um movimento desgovernado: de casa para a rua, de volta a casa, de casa a um cafofo, do cafofo para as ruas; e tira-lhe a pele, metáfora construída com efeito fortemente realista, ante a sensação de calor e queimadura que emana de cada toque em um móvel, de cada recepção do vento, do leve sinal de que alguém vai apenas lhe esbarrar: são microelementos que compõem microespaços que compõem o espaço urbano.

Naquele espaço de casamento, antes de ler o diário, passavam-se cenas corriqueiras, domésticas, como conversas sobre ter ou não ter filhos ou busca de boletos para pagamentos de contas. Apesar de até então parecer um cosmos e ser assim considerado pelo narrador, a casa já elucidava algo contrário ao seu caráter de abrigo: certa animosidade, certo desconforto, mesmo que ainda não compreendido:"Perguntei, rindo e sentindo algum acolhimento, se ela queria começar a fazer nosso filho naquele momento. Quando terminei a frase, alguma coisa me emocionou. Outra vez, sem nenhuma hostilidade, ela me afastou. Logo, adormeceu". (LÍSIAS, 2013, p. 24)

Desde sempre, então, esse cenário de trivialidades se desvirtuava para uma função de desabrigo. Não é por acaso, então, que ali se dará o encontro do diário, a leitura casual de uma linha, a decisão difícil de ler todas as linhas: 
Lembrei-me de uma conta que precisava pagar naquele dia. Abri a gaveta da minha ex-mulher e vi o boleto no meio de um caderno. Li uma frase e minhas pernas perderam a força. Sentei no lado dela da cama e por um instante lutei contra mim mesmo para tomar a decisão mais difícil da minha vida. Resolvi por fim ler o diário da primeira à última linha de uma vez só. (LÍSIAS, 2013, p. 25).

O diário passa a fazer parte, assim, das representações vinculadas à espacialidade que compõe a narrativa - o diário dentro da casa, a casa dentro da rua, a rua dentro da cidade -, pois ele será também um espaço percorrido: suas linhas serão frequentadas insistentemente, repetidamente, o que ilustra os estudos de Brandão vistos nos segmento anterior. O teor da primeira frase, por exemplo, detona a saída do narrador de sua casa para o cafofo e para a rua, num atravessamento incessante entre essas extensões. Os registros são um espaço de leitura (da mulher quanto a ele; dele, memorialmente, quanto a si e a ela, quanto ao período em que estiveram casados; e quanto a si mesmo como escritor) que traumatiza a vida do narrador, provocando a perda da sua pele, tornando seu corpo um espaço de visível desproteção. Impulsiona-o para a rua, para quilômetros a serem percorridos em uma corrida frenética; é, por fim, um objeto discursivo que funciona como ponto de partida para que o narrador se destroce de si mesmo, construindo um movimento que resulta em um outro espaço, materializado e discursivo: uma obra literária intitulada Divórcio, que chega até o leitor.

Entre os efeitos da leitura do espaço discursivo diário, o primeiro é, então, a alteração do espaço físico em que se encontra o narrador. O apartamento (domus) fica tomado pelo silêncio e tensão, o que foi seguido por ações rápidas e encadeadas de recolha de um objeto aqui, outro ali, ainda algum acolá, em um arranjo agitado, exaltado, de fuga, para, enfim, o protagonista alcançar a rua. Em seguida e no mesmo ritmo, o retorno rápido a casa, apenas para pegar o diário, xerocá-lo, devolvê-lo ao lugar de origem. A partir de então, o enredo passa a se constituir de uma viagem aos seus quatro meses de casado, entremeada pela visita constante a trechos do diário e ao passado.

Simultaneamente, o protagonista chega ao cafofo, onde se dá a cena inicial da narrativa, momento em que ele se vê fora de seu corpo. Esse segundo espaço de dentro será um substituto do primeiro no sentido físico de ocupação, entretanto, sem a ilusão da estabilidade, pois ele é apenas um ponto geográfico de apoio, para onde o narrador vai, de onde sai, para onde retorna. Da mesma forma que a casa, o cafofo é parte da rua, de uma rua dentro de uma cidade. É nele que o narrador se descobre um outro, um corpo, e um corpo sem pele, desprotegido. O cafofo é, assim, pouco descrito e vale mais como uma referência para o narrador, para ter para onde voltar e de onde sair. Não se trata de um posto de paragem:

Achei-a delicada e me emocionei. Na hora que saí, fiz questão de agradecer. Ela talvez tenha achado um exagero. Voltando para o cafofo, procurei refazer na memória o rosto da moça. É bonita, concluí. Não sei o que aconteceu nesse intervalo. Agora, vejo-me de novo na avenida movimentada. (LÍSIAS, 2013, p. 12).

Seu espaço físico de maior constância será mesmo a rua (elemento por excelência do espaço urbano), o lugar realmente seu, entretanto, não em continuidade nem em fixação em nenhum dos pontos que pertencem à via pública e frequentado sem disciplina, aleatoriamente, a serviço do estado emocional em que se encontra. Mais uma vez, o espaço vai funcionar como condição de vivência subjetiva, portanto, ele não tem valor em si mesmo, mas é algo que se projeta sobre o narradorpersonagem, permitindo que ele projete suas sensações e aprendizagens, estas que se dão de forma intensa e dinâmica. A cidade deixa de ser em sua geografia e passa a ser a incorporação de uma subjetividade.

Não é por acaso, então, que os títulos dos capítulos da narrativa sejam encabeçados pela expressão "Quilômetro um”, "Quilômetro dois"... até que o narrador tenha percorrido 15 quilômetros, o último, "Quilômetro quinze". Essa travessia não é feita por um flâneur, um apaixonado pelas ruas e que delas usufrui deleitosamente, descrevendo-as, tornando-as visíveis protagonistas em seu estado de 
urbanidade. Diferentemente, as ruas, em Divórcio, são secundárias, não apresentam detalhes que as tornem reconhecidas como extratextuais: nem uma árvore representativa, nem uma loja, nem uma esquina, nem um edifício, nada que identifique por onde ele anda, nada que personifique o espaço. As ruas cedem sua relevância como categoria na qual se inserem personagens e enredos para um protagonista perdido, sem rumo, desprotegido, sem pele, que anda por elas como uma forma de expelir os pensamentos sufocantes emanados da leitura do diário. A rua não é o objeto de observação nem o de desestabilidade, o verdadeiro objeto transita por ela: ele é o próprio narrador, sujeito do espaço urbano carregado de indiferença. Por isso, abaixo de cada título de cada capítulo, há um subtítulo que alude a algo desse narrador-personagem. Sob "Quilômetro dois", por exemplo, vem a expressão "um trem passando dentro de mim", referindo-se ao narrador; sob "Quilômetro cinco", "não tenho dificuldades para achar amantes", uma fala da ex-mulher encontrada no diário, mas que reflete o estado do narrador, boquiaberto e sofrido ante a declaração.

Sendo, assim, a expressão do narrador-personagem, a rua permite um passo a passo, um quilômetro a quilômetro que lhe possibilita um itinerário próprio. "Durante esse" percurso - e não "nesse" percurso - , a princípio, de desamparo, o protagonista encontrará em si mesmo uma forma para ter um rumo, não um rumo geográfico, mas um rumo para sua existência. Seu corpo é o espaçoinstrumento com o qual ele percorre as ruas; é o espaço que ele transforma. E faz isso pelo movimento desse mesmo corpo, por meio da prática da corrida. Significativamente, o exercício físico conota o percurso interno do narrador: ao mesmo tempo em que atende às necessidades de um ser irrequieto, conturbado, convulsionado, desvairado, desnorteado, naquele momento, sem pele, coloca esse alguém em uma dinâmica que lhe desenvolve a concentração em si mesmo, a resistência aos outros. A isso serve o espaço urbano, elemento onde o narrador pode dar vazão a sua dinamicidade. Correndo, vai dando conta de seu processo de reação à leitura do diário: estar sem pele, ir adquirindo nova pele, tornar-se um homem com nova pele, um verdadeiro corpo-espaço em (re)construção. No entanto, essa nova envoltura não é a de alguém com estabilidade, porque o protagonista é, em si mesmo, um ser perenemente instável; o máximo que ele consegue é ter uma mínima rotina na vida, o suficiente para ser ele mesmo e o que o diário the havia tirado. $\mathrm{O}$ casamento havia sido apenas uma ilusão de estabilidade, pois, até no decorrer daqueles quatro meses, o narrador-personagem não conseguia atender sequer às estabilidades triviais, conforme as próprias palavras da esposa ilustram:

Esses caras que leram demais são muito fechados. Meu marido é muito esquisito. O Ricardo reclamou da fila da Broadway. Ele vai ficar dez dias em NY e não vai ver um espetáculo da Broadway! Ele leu muito, mas não sabe que pela Broadway passaram os grandes atores que começaram a vida lá. Ele quer andar na rua! O Ricardo leu muito, mas não sabe nada. (LÍSIAS, 2013, p.73).

Por isso é que, também não por acaso, um dos campos semânticos dominantes na narrativa pertença ao espaço exterior, a rua, urbano por excelência. Primeiramente, os elementos citados para demarcar o espaço são pertinentes a ela — metrô, plataforma, estação, vagão, avião, aeroporto, ônibus, etc. entretanto, não restritos ao período pelo qual passa o narrador. Os casos que conta do seu passado, infância e juventude, carregados de situações extratextuais, dinâmicas e agitadas, ratificam isso: "No caminho até o aeroporto da minha primeira viagem de avião, percebi que a careca do meu avô tinha um machucado". (LÍSIAS, 2013, p. 31).

A pele ferida de um rosto e os trens estão na minha lembrança mais antiga. Foi em 1980 ou 81. Minha mãe não soube precisar. Consultar o resto da família seria muito doloroso. Eu tinha por volta de cinco anos.

Da nossa casa até a dele, o caminho custava mais de duas horas e exigia um ônibus, dois metrôs e por fim a única parte que eu gostava: uma viagem de trem entre a estação Júlio Prestes e a de Osasco. (LÍSIAS, 2013, p.41).

Em 2002, juntei dinheiro para visitar a Irlanda. Minha ideia era ficar uma semana em Londres, para 
onde não tinha voltado desde o intercâmbio maluco anos antes, e depois passar outros sete dias na cidade de Joyce e Beckett. Achei que seria mais agradável evitar os aeroportos e resolvi tomar um ônibus até onde partem as balsas da costa inglesa. Para não cansar muito, fiz uma parada na feia Birminghan. De lá, tomei outro ônibus para amanhecer no porto e atravessar para a Irlanda (LÍSIAS, 2013, p.49).

Ainda as metáforas para ilustrar como se sente o narrador,emoldurado pelo espaço urbano, são também da mesma área do movimento externo ("[...] como se um trem estivesse passando dentro de mim" (LÍSIAS, 2013, p. 29); "O mundo continua em silêncio, mas agora eu já não me sentia tranquilo. Preciso atravessar dois cruzamentos" (LÍSIAS, 2013, p. 28)); e da necessidade de não estar em espaços restritos. Tanto é assim que um dos trechos do diário mais visitados é a frase com que a ex-mulher o descreve, restringindo-o a um ocupante de espaço exíguo: "Casei com um homem que não viveu. O Ricardo ficou trancado dentro de um quarto lendo a vida toda". (LÍSIAS, 2013, p. 15).

Todo o envolvimento com o externo traduz, então, um narrador que vive em trânsito - entra em um casamento de solidez ilusória; sob forte impacto, sai desse casamento; sente-se perdido, deslocado, sem coordenadas; tenta encontrar, nesse turbilhão, algo em que se apoiar. Assim, no decorrer do primeiro quilômetro, a sensação é de enfraquecimento, ausência de pele, dor ao menor toque, sensibilidade à flor do nada. Nos seguintes, ele caminha sem saber exatamente os roteiros pelos quais passa. Contudo, gradualmente, vêm as mudanças, sob efeito do caminhar, do andar mais rapidamente, do correr: sem pele, com um pouco de pele, com pele. Ao longo do percurso, as ruas são lugar de perdição, de desencontro e encontro consigo mesmo. Não há uma descrição de lojas, de praças, de letreiros que dê pistas e roteiros. Não há paredes a serem pichadas. A cidade se perde. Só há ele, o narrador-protagonista, que sente seu desvario, seu riso, seus passos, e, por fim, um corpo sob domínio, com percepção até de braços:

Quem pensa sem ar: ninguém, por exemplo. Você pode chorar desesperadamente na avenida mais importante da América Latina. Ninguém vai te ajudar. Ninguém me perguntou nada quando entrei na linha errada do metrô e olhei confuso para o letreiro. Eu precisava que um velho me dissesse algo, ou uma moça, mas ninguém me olhou no metrô de São Paulo no pior dia da minha vida. (LÍSIAS, 2013, p.9).

Na estação seguinte, percebo que estou no caminho contrário do cafofo. Desço e procuro o lugar certo. Não consigo encontrá-lo, mas, como a plataforma me parece mais segura, resolvo andar. Não lembro quanto tempo fiquei vagando. Mas o cansaço afastou o trem que estava passando dentro da minha cabeça. (LÍSIAS, 2013, p. 29).

[...] Tomei um táxi e ele logo chegou. Olhou-me como apenas dois homens que se conhecem muito bem são capazes e na mesma hora me abraçou e me emprestou um pouco de pele. Me dá isso. Ele pegou a cocaína e jogou no bueiro. Agora, Ricardinho, vamos pichar o Itaú! Pichar com o quê? Repeti aquela cena ridícula de quem ri quando está chorando feito um doido. Meu primeiro dia fora de casa estava nascendo (LÍSIAS, 2013, p. 39).

No final do espaço que a agenda separava para aquele dia, escrevi com letras maiúsculas: NÃO MANDAR MAIS E-MAILS, SMS OU TELEFONAR PARA ELA, NUNCA MAIS. Saí para andar um pouco e senti algum ânimo para apertar o passo. Se ficasse cansado, ao menos tinha alguma esperança de dormir. (LÍSIAS, 2013, p.66).

Mais cinquenta metros e essa subida acaba. Dá para ver o pessoal chegando lá em cima. Eles se viram, alguns dão pequenos saltos e vários erguem os braços. Eu mesmo estou a poucos metros. Seria um erro tentar chegar à situação do meu corpo agora. Nada vai me impedir de subir correndo esses últimos dez metros. Prefiro quebrar a perna ou desmaiar sem fôlego. A gente vira especialista em medições: cinco, quatro. Sou um engenheiro com uma fita métrica. Na verdade, sou um atleta. É como me sinto agora aqui em cima, olhando para trás. Meus braços também estão para o alto.

Acabou. (LÍSIAS, 2013, p.229). 
Ao contrário da casa, a rua é, então, um espaço de extensão onde o corpo atua. Os títulos dos capítulos, sempre quilômetros, conotam o prolongamento, algo que permite a dispersão de um narrador inquieto, cujo corpo não se posiciona fixamente em espaço nenhum, a cidade é espaço nenhum. Pelo contrário, expõe-se como um movimento mais que geográfico, é social e filosófico; mais que social e filosófico, é intrínseco ao narrador-personagem. O desassossego é sua condição, a qual, sob a impulsão do diário, torna-se desnorteamento. Sem pele, invisível para os transeuntes, tem seu gosto por andar transformado em compulsão. O diário, esse agente de perturbação, passa a ser um lugar frequentado como forma de alimentar essa perturbação, que se faz e se desfaz em um atravessamento de 15 quilômetros, num ascendente esforço de correr, desafiando o próprio corpo.

Todos os espaços - casa, diário, cafofo, corpo, rua, a cidade, enfim - em suas idas e vindas, inserem-se em um outro espaço, uma obra literária, Divórcio, cuja construção está entremeada ao enredo, produzida pelo narrador-personagem, um escritor, Ricardo Lísias. Todos eles preenchem os capítulos ordenados por uma sequência espacial — "Quilômetro um", "Quilômetro dois"... até "Quilômetro quinze". Há, dessa forma, uma projeção desses espaços em uma condição espacial estendida em um enredo, no qual atuam narrador, personagens, espaços, categorias esteticamente postas e amarradas a esse desnorteio do narrador-escritor: a escrita da obra, alongada em capítulosquilômetros, empreende a reconstrução de alguém “despelado" pela leitura de um diário, um espaço discursivo em cujas páginas é alvo de críticas; de alguém que, percorrendo espaços, tentando adquirir nova pele, escreve. Essa voz coloca seu mérito de escritor em questão, o que é impulsionado novamente pela leitura do diário, que desestrutura o personagem na sua função de marido e na sua função de escritor, servindo como um troféu, como objeto promovedor de status:

Ele viveu aventuras e sabe que o cinema é igual jornalismo: é vida. E o Ricardo? Por acaso o Ricardo foi para alguma guerra na África? O que ele sabe da vida? Ele não me dá nenhuma das aventuras que eu preciso. (LÍSIAS, 2013, p. 80-81).

O Ricardo é legal, inteligente e às vezes me diverte, apesar de andar muito. Mas apaixonada eu não estou. Eu não sei o que vai ser quando voltarmos ao Brasil. Eu gosto de ser casada com um escritor. É só esconder certas coisas e pronto. [...] O Ricardo é um retardado, não tenho dúvidas, mas mesmo assim é um escritor, o que me preserva de certas coisas. (LÍSIAS, 2013, p.90).

O que deixou meu corpo morto, no entanto, não foi nada disso. A seguinte frase tirou-me toda a pele: Casei com um homem que não viveu. O Ricardo ficou trancado dentro de um quarto lendo a vida toda. (LÍSIAS, 2013, p.122).

Para salvar-se do menosprezo, para entender como lhe fora possível ter dito sim a um casamento com uma pessoa tão pouco afeita ao companheirismo e ao respeito, o narrador escreve, mas não considera que essa prática surtirá o efeito pretendido, desconfiando de seu próprio fazer literário: "Por que eu disse sim? Acho que nem esse livro vai me dizer. Poucas coisas são mais ridículas, e de novo clichês, do que gente que subiu na vida trabalhando. Aceitei casar com uma pessoa que progrediu com o próprio suor..." (LÍSIAS, 2013, p. 103). Em suas tentativas de salvação ante a destruidora leitura do diário, o protagonista ironiza a ex-mulher, transforma sua maneira de escrever na metonímia de sua mediocridade como pessoa, ambas clichês, a má pessoa é a jornalista que escreve mal, uma pós-doutoranda em clichê. Compara, para compor essa catarse, o seu próprio trabalho com o dela, demonstrando como a escrita exige exercício: "Infelizmente, nunca conversei com a bem-sucedida sobre o tal processo criativo. Este romance, portanto, tem um trecho incompleto. Não vou decepcionála, porém: crio um plano e sempre prefiro cumpri-lo. Se as coisas dão errado, paro e o refaço". (LÍSIAS, 2013, p. 105).

Entretanto, apesar de desconfiar de si, é por essa mesma escrita que o narrador-escritor se encontra, equivalendo seu fazer literário a seu processo existencial - momentos de fracasso são fracassos que indiciam aprendizados; aprendizados que promovem esperança: 
O capítulo fracassou. Meu plano inicial era lembrar tudo o que vivi de bom com minha ex-mulher para entender por que resolvi me casar. Na economia do romance, seria o momento de descrever o que ela fez por mim, os passeios, as conversas e sobretudo como cultivei o amor que comecei a sentir no lançamento de O livro dos mandarins.(LÍSIAS, 2013, p.131).

Divórcio é um livro repetitivo. Já escrevi algumas vezes que o fato de concluir algo que eu tenha planejado me faz bem. Mas como minha cabeça se desarranjou completamente, cada confirmação é um sinal de esperança [...] Escrevo esse trecho um ano depois de sair de casa. Minha pele já voltou. Está novinha. Não sou a mesma pessoa, claro, mas superei quase tudo. Só tenho raiva de ser obrigado a levar essa história pelo resto da vida. Um clichê: um jurado humanista do Festival de Cannes e a Catedral de Notre Dame. (LÍSIAS, 2013, p.173).

Assim vida e romance seguem em paralelo, nas mesmas ruas, pelos mesmos trajetos:

A variação estilística do livro chama minha atenção. O começo é tenso e cheio de incertezas. Treme, por assim dizer. Acho que representa bem a situação de enorme angústia que vivi. Comecei a escrever exatamente depois da corrida que vou narrar no próximo capítulo. Ela me trouxe pele nova. (LÍSIAS, 2013, p. 212).

\section{Conclusão}

A obra Divórcio é, portanto, um espaço de linguagem que se revela em três instâncias, construídas no espaço urbano. A primeira é o espaço onde se estrutura a experiência vivida pelo narrador-escritor, sem elementos de localização que definam o espaço, que o descrevam e assim lhe tragam segurança, de forma que não há um "onde", um "por onde",um"aonde". As ruas e avenidas percorridas são apenas ruas e avenidas, sem diferenciadores, sem elementos distintivos, sem pontos de partida ou de chegada (a lanchonete é uma lanchonete; o vagão de metrô é um vagão; cruzamentos não têm nome; o cafofo, um pontículo onde paira o narrador-escritor, por momentos, sem dele se apropriar, e fica próximo ao ponto principal de travestis de São Paulo; a casa, distanciando-se do narrador a cada por ele quilômetro percorrido, algo remoto). Dessa forma, a representação da categoria espaço é interrogada como valor em si, tornando-se um arcabouço para a configuração da voz do narrador, a segunda instância em que o espaço se revela. Perde-se o espaço físico, urbano, a cidade, para que o homem que nela vive passe a figurar, ritmando o movimento do texto de acordo com as suas necessidades: anda mais rápido e dispara no trote para fugir de ouvir seu coração acelerar; caminha para aliviar a raiva; faz percursos longos para sentir o corpo vivo. Assim a narrativa é frenética, acelerada, quando emocionalmente o descontrole do narrador é maior, significativamente quando mais próximo da descoberta do diário ou quando o frequenta; apresenta hiatos percebidos pelo próprio narrador, que nos revela não saber onde esteve e o que fez em determinados momentos; ou ainda calmo, conseguindo disciplinar uma passada depois da outra, quase todas iguais, quando sente que já está vencendo a corrida contra a frustração vivida e já não frequenta o diário. Nesse espaço de linguagem, então, dá-se a concretude da palavra, a terceira instância, aquela que se mostra como "re-ação" à leitura do diário, palavra esteticamente posta, entremeio entre literatura e experiência: "Repeti os capítulos anteriores. Quero muito ser forte: preciso de mil repetições!” (LÍSIAS, 2013, p. 219). Palavra que diferencia criticamente sua própria produção: "Pela primeira vez em seis meses, peguei a cópia do diário da minha ex-mulher e, como tinha feito antes, li tudo de uma vez só. Nunca ninguém me ofendeu tanto. Mas o texto é brega e mesquinho. Uma enorme e pretensiosa tolice. Joguei-o no lixo". (LÍSIAS, 2013, p. 231).

Tem-se, assim, um espaço urbano como um espaço de errância, interno ao narrador, sendo negado como espaço de ancoragem, sendo de alguma forma faltoso.

O protagonistanão permanece no espaçourbano em que está, não está salvaguardado nele como um todo nem em seus subespaços. Ele não olha para a cidade em seu todo, mas dirige-se a espaços vários, 
sempre em deslocamentos físicos e/ou mentais, como aventura (in)voluntária para o deciframento de si. A cidade não é um lócus de ajustamento mas de deriva.

Se papel é algo secundário, vive para ilustrar esteticamente a instabilidade interna do protagonista, este que não atua como um cidadão, como alguém "da" cidade, mas alguém "na" cidade (grifos nossos), incapaz de centrar-se, em dificuldade de centrar-se nesse espaço urbano, de ter nele um apoio. O meio urbano não vale por si, é um cenário que está ali, apenas. Traduz-se por meio de mecanismos que retratam o protagonista, desalojado, sem lugar, embora esteja em uma cidade. Ela não lhe dá a sensação de pertencimento. É um espaço-cidade, de trânsito, de um cômodo para uma casa, da casa para um cafofo, do cafofo para a rua, para a casa, para o cômodo... Deslocado e deslocando-se, esse ser em discurso está sempre em busca de si mesmo (por vezes, na fuga de si mesmo). Tomemos aqui, metaforicamente, a fala de Kristeva, “o estrangeiro habita em nós” (KRISTEVA, 1994, p. 9): um personagem que, mais que não se vê na cidade, parece indiferente a isso, negando-se a olhar para ela. Esse estado de estrangeiridade em si mesmo é o que leva o homem para uma fuga intencional para descobrir-se em espacialidades, não no espaço, descobrir-se nos (des)caminhos que lhe são postos discursiva e esteticamente. Apropriando-nos da fala da estudiosa, é possível dizer que a voz presente naobra em estudo expõe a estranheza que há em si mesma, alheiamente à cidade, um espaço sem nome e que também não nomeia.

O prisma com que se apresenta a espacialidade saide sua cristalização, e ela fica perceptível sob outras condições, agora tensionadas pela transposição feita pela autoria do espaço real para o espaço de representação. Essa representação se desloca do ordenado, divorcia-se dela, constituindo sua existência como se fora do espaço-cidade transferindo-se para o espaço-linguagem. Trata-se de uma construção desconfortável porque não está no real (costumeiro, previsível) nem na utopia (consoladora porque está no limiar do maravilhoso). Está nas heterotopias, espaços de não acolhimento, desviantes da linha definida da linguagem:

O tensionamento da representação espacial - enfim, do efeito obtido pela aceitação tácita de que espaços podem ser transpostos do mundo para o texto - se dá precisamente pela radicalização do significado da ação de transpor, a qual passa a ser entendida como de interferência, dinamização, provocação, desestabilização. Trata-se, portanto, de uma ação política. (BRANDÃO, 2013, p.67).

Na cidade, o protagonista não tem asilo, não pode "con-viver", não se centra o suficiente para isso, são "des-centrados" espaço e protagonista. A geografia urbana é cambiante, errante, um mero espaço para o narrador desenrolar-se de si mesmo. O espaço urbano é uma subversão. 


\section{Referências}

BACHELARD, Gaston. A poética do espaço. São Paulo: Martins Fontes, 1988.

BRANDÃO, Luís Alberto. Teorias do espaço literário. São Paulo: Perspectiva; Belo Horizonte: Fapemig, 2013.

KRISTEVA, Julia. Estrangeiros para nós mesmos. Rio de Janeiro: Rocco, 1994.

LÍSIAS, Ricardo. Divórcio. Rio de Janeiro: Objetiva, 2013.

MORETTI, Franco. Atlas do romance europeu. São Paulo: Boitempo, 2003.

REIS, Carlos; LOPES, Ana Cristina M. Dicionário de narratologia. Coimbra: Almedina, 1987.

SANTOS, Luís Alberto Brandão; OLIVEIRA, Silvana Pessôa de. Sujeito, tempo e espaços ficcionais: introdução à teoria da literatura. São Paulo: Martins Fontes, 2001.

WINK, George. Topografias literárias e mapas mentais: a sugestão de espaços geográficos e sociais na literatura. In: DALCASTAGNÈ, Regina; AZEVEDO, Luciene (Org.). Espaços possíveis na Literatura Brasileira contemporânea. Porto Alegre: Ed. Zouk, 2015. p. 21-33. 
